\title{
Exploring the Feasibility of Using Silage-Based Feed with Alternative Sources of Protein in Organic Pig Rations
}

\author{
Ruth C. Clements ${ }^{1, *}$, Laura E. Higham ${ }^{1}$, Jo Smith ${ }^{2}$, Catherine L. Gerrard ${ }^{2}$, Mike C. Colley ${ }^{1}$, Konstantinos Zaralis ${ }^{2}$, \\ Rebecca Nelder ${ }^{2}$, Bruce Pearce ${ }^{2}$, Annie Rayner ${ }^{1}$ and Ashleigh Bright ${ }^{1}$ \\ ${ }^{1}$ FAI Farms Ltd, The Field Station, Wytham, Oxford, UK \\ 2 The Organic Research Centre, Elm Farm, Hamstead Marshall, UK
}

* Corresponding author: E-Mail: ruth.clements@faifarms.com; Tel.: +44 1865790880; Fax: +44 1865251811

Submitted: 18 May 2015 | In revised form: 19 October 2015 | Accepted: 21 October 2015 |

Published: 5 November 2015

\begin{abstract}
Current regulations for organic pig and poultry production systems permit feed ingredients of non-organic origin at an inclusion rate of up to 5 per cent. This is primarily due to concerns that there is an insufficient supply of organic protein on the European Union market, in terms of quality and quantity, to meet the nutritional requirements of pigs and poultry raised on organic farms. However, 100 per cent organic diets for monogastric livestock will become compulsory in the EU from 1 January 2018, and there is therefore a need to develop sustainable feeding strategies based on organic feeds. This feed trial conducted in the UK explores the feasibility of using a silage-based feeding system for Gloucester Old Spot pigs, and compares the inclusion of soya, beans and peas as protein sources in terms of pig growth performance. No significant difference in the pen mean daily live weight gain was observed during the grower phase (pen mean age of 11-14 weeks) between the diet groups. However, during the finisher phase (pen mean age of 15-22 weeks), pigs on the soya and pea rations had significantly faster growth rates than pigs fed the bean ration. It is speculated that the slight shortfall in growth rate observed in the pigs fed the bean ration may be offset by the lower cost of production of beans in the UK. This feasibility trial demonstrates that a 100 per cent organic diet for pigs using alternative, locally-grown sources of protein as part of a forage-based ration can provide a viable alternative to a soya-based diet.
\end{abstract}

Keywords: beans; forage; monogastrics; organic; peas; pigs; roughage; silage; soya; soybean

\section{Introduction}

According to European regulation ((EC) No 889/2008 and (EU) No 836/2014), organic producers will be required to provide 100 per cent organic feed to pigs (Sus scrofa domesticus) from 1 January 2018. The current derogation allows the inclusion of up to 5 per cent non-organic feed ingredients. The transition to 100 per cent organic pig rations requires the development of viable and sustainable feeding strategies based on locally-grown organic feed, which fulfils the nutritional requirements for pig health and welfare.

The transition to 100 per cent organic pig rations presents a number of technical and sustainability challenges to the pig industry. One hundred per cent organic rations have been associated with dietary deficiencies in amino acids due to the difficulties in formulating rations of high nutritional density and balanced amino acid profile under organic management; the supplementation with 
synthetic amino acids or those manufactured in a fermentation process is prohibited in organic systems; there is a ban on feeding certain animal by-products; and there is substantial variation in the feeding value of home-grown forage and protein crops [1]. Soybean meal provides a highly digestible and amino acid-rich source of protein in monogastric rations [2]; however, it is not widely grown in Europe and imported soya is associated with negative environmental and social impacts. For example, the expansion of soybean production in countries such as Brazil, which has seen an increase in production by 357 per cent between 1990 and 2011 [3], has resulted in the loss of natural ecosystems and threats to biodiversity [4]. The requirement for land has also displaced smallholder farmers to make way for larger farms [4,5]. European-grown alternative protein sources such as lupin (Lupinus albus, L. luteus, L. angustifolius) and naked oats (Avena nuda) are available, but only partially fulfil the requirement for the essential amino acid methionine of growing pigs [6]. In addition, the provision of sufficient methionine and lysine in alternative protein sources is often accompanied by the over-supply of total protein, with the associated negative environmental effects of nitrogen excretion and emission of greenhouse gases, and the adverse impacts of high dietary contents of protein and anti-nutritional factors on piglet health $[1,7]$.

In light of these numerous challenges and with feed accounting for up to 65 per cent of conventional pig production costs in England [8], a sustainable solution to organic pig nutrition is required, with equal consideration of the economic, environmental and ethical impacts (the '3Es') [9].

It is widely understood that herbage has the potential to make an important contribution to pig nutrition [10,11], and could play a greater role in organic pig production. Pigs are naturally opportunistic foragers and omnivores. The intestinal microbiome of the porcine hindgut can digest cellulosic, fibrous feed and accounts for 48 per cent of the pig's fermentative capacity [12], enabling them to digest a variety of other foodstuffs including plant materials such as grass. Notwithstanding the limitations of including forages as dietary components, in terms of reducing digestibility and energy availability from the overall ration [13], herbage can make a valuable contribution to nutrition at all stages of pig development. It offers a source of minerals and vitamins, enhances feed intake, and supports gut health by reducing the risk of gastric ulceration associated with grain-based feeds [14-16]. The provision of forage can support positive gut colonisation, which inhibits pathogenic microbes [16], and Danielsen et al. [17] found a tendency towards improved feed utilisation when clover grass was included in concentrate-based rations for finishing pigs.

Herbage-based diets facilitate foraging behaviours that engage pigs in the natural activities of searching for food, rooting and chewing for two thirds of their time [18]. This also fulfils EU legislation to provide pigs with access to manipulable materials. According to Studnitz et al. [19], "ex- ploratory behaviour in pigs is best stimulated by materials that are complex, changeable, destructible, manipulable, and contain sparsely distributed edible parts". FAI Farms has utilised a home-grown silage-based ration in its strawyard pig production system for over 10 years, and high levels of natural foraging behaviours and minimal aggression such as tail-biting behaviours have been observed (Anna Wharton, University of Oxford, Oxford, UK. Conversation with Laura Higham, 27 January 2015.). This natural foraging behaviour and reduced aggression has removed the need for tail docking in this herd.

The present feasibility study compared the growth performance of grower-finisher pigs, fed on a novel silagebased diet with soya as the protein source, to that of grower-finisher pigs fed on two different silage-based diets that contained either field beans (Vicia faba) or peas (Pisum sativum) as replacement of the soya protein source. The protein sources were compared in a practical farm setting on an 'as-fed' fresh weight basis. The stomach mucosae of a sample of pigs at slaughter were also assessed to explore the effect of silage-based rations on gastric health. The current study was conducted in the UK as part of project 'The Improved Contribution of local feed to support 100 per cent Organic feed supply to Pigs and Poultry' (ICOPP) [20,21].

\section{Materials and Methods}

A two-part controlled feeding trial was conducted at FAI Farms in Oxford, UK, from August to November 2012 ('summer trial') and from February to May 2014 ('winter trial').

\subsection{Animals and Experimental Design}

Forty-six and fifty-six home-reared Gloucester Old Spot weaner gilts and entire boars entered the summer and winter trials, respectively. Gloucester Old Spot pigs are a traditional English breed [22], and are relevant to organic pig production in the UK. This breed of pig has been utilised in FAl's home-reared, closed herd for ten years, thus offering pigs of a known high health status to this study. Pigs were sex segregated and randomly assigned to one of three groups using a blocked randomisation list [23] (refer to Table 1). The control treatment groups, consisting of one male and one female pen in each of the summer and winter trials, received a daily ad-lib total mixed ration (TMR) comprising home-grown lucerne silage chopped to a length of 5-8 cm using a Kennan mixer wagon (Richard Kennan UK Ltd, Warwickshire, UK), home-grown rolled barley, minerals and soybean meal. The two treatment groups, each consisting of one male and one female pen in each of the summer and winter trials, received a daily adlib TMR composed of home-grown lucerne silage chopped to a length of 5-8 cm using a Kennan mixer wagon, homegrown rolled barley, minerals and milled field beans ( $\mathrm{Vi}$ cia faba; group 1) or milled peas (Pisum sativum; group 
Table 1. Arrangement of pens as part of the feed trial to compare silage-based rations including different protein sources (diet).

\begin{tabular}{lcclc}
\hline Trial & Pen number & Diet & Sex & Number of pigs \\
\hline Summer & 1 & Soya & Male & 7 \\
& 2 & & Female & 8 \\
& 3 & Beans & Male & 8 \\
& 4 & & Female & 8 \\
& 5 & Peas & Male & 7 \\
\multirow{4}{*}{ Winter } & 6 & & Female & 8 \\
& 1 & Soya & Male & 8 \\
& 2 & & Female & 9 \\
& 3 & Beans & Male & 8 \\
& 4 & & Female & 11 \\
& 5 & Peas & Male & 9 \\
& 6 & & Female & 11 \\
\hline
\end{tabular}

2). The proportions by fresh weight of the lucerne silage, barley, minerals and the protein source comprising the diets were equal across all three treatment groups and remained constant throughout the trial period, as shown in Table 2. Diets were formulated as such to meet the nutritional requirements of pigs according to Whittemore et al. [24] (Table 3) as closely as possible in all three diets.

The pigs were housed in groups of between seven and eleven, in indoor straw yards of dimensions $8.3 \mathrm{~m} \times 4.3 \mathrm{~m}$
(35.7 $\mathrm{m}^{2}$ in area), with woodchip-straw bedding in the rear third of the pens and concrete floors to facilitate floor feeding. Water was continuously available from three drinking valves in the front of the pen. Temperature was not controlled, although the pens were sheltered from rain and wind. All piglets recruited into the trial were home-reared with access to the same forage-based diet in family pens from two weeks of age. Mean pen age at recruitment into the trial ranged from eight to ten weeks.

Table 2. Percentages of feed ingredients comprising the total mixed ration (TMR) by weight, as fed, used for three groups of pigs as part of the feed trial.

\begin{tabular}{llccccc}
\hline \multirow{2}{*}{ Treatment group } & \multirow{2}{*}{ Protein source } & \multicolumn{4}{c}{ Percentage of feed ingredients in TMR by weight (\%) } \\
& & Lucerne silage & Rolled barley & Minerals & Protein source & Total \\
\hline Control group & Soybean meal & 55 & 30 & 1 & 14 & 100 \\
Group 1 & Beans & 55 & 30 & 1 & 14 & 100 \\
Group 2 & Peas & 55 & 30 & 1 & 14 & 100 \\
\hline
\end{tabular}

Table 3. Nutritional requirements and expected feed intakes of pigs [24].

\begin{tabular}{|c|c|c|c|c|}
\hline \multirow[t]{2}{*}{ Requirement, Expected feed intake } & \multicolumn{4}{|c|}{ Pig body weight (kg) } \\
\hline & $15 \mathrm{~kg}+$ & $25 \mathrm{~kg}+$ & $40 \mathrm{~kg}+$ & $60 \mathrm{~kg}+$ \\
\hline Metabolisable energy (ME; MJ day ${ }^{-1}$ ) & 10.1 & 12.8 & 22.17 & 26.87 \\
\hline Crude Protein (CP; g day ${ }^{-1}$ ) & 185 & 219 & 270 & 310 \\
\hline Lysine $\left(\right.$ g day $\left.^{-1}\right)$ & 9.5 & 10.9 & 13.8 & 25 \\
\hline Voluntary feed intake (kg DM day ${ }^{-1}$ ) & 1.25 & 1.75 & 2.5 & 3.5 \\
\hline
\end{tabular}

\subsection{Measurements and Sampling}

Pigs were fed each morning on an ad-lib basis. The weight of feed provided per pig was increased incrementally over the trial, and leftover feed was removed and weighed each day to ensure that pigs were offered an amount in excess of consumption, and to ensure the provision of fresh feed each day.

Nutritional analyses of the ration components (homegrown forage was analysed by Independent Soil Services, 
Norfolk, UK) were used to calculate the nutritional values of the three mixed rations per kilogram fresh weight (Table 4), allowing any feed deficiencies to be identified based on the nutrient requirements of pigs defined by Whittemore et al. [24]. All three diets were balanced in their supply of crude protein and energy, fulfilling the requirement of the pigs at each stage, but lysine deficiencies were noted in all rations, which is a common constraint in organic production. All pigs were weighed individually using calibrated weighing scales (Pharmweigh, Bury St. Edmunds, UK) on a weekly basis, and the pen mean daily live weight gain was calculated. Daily live weight gains 'd' of individual pigs were derived on a weekly basis using the following formula, and a pen mean was calculated.

$$
d=\frac{w_{x}-w_{x-1}}{7}
$$

where $d=$ daily live weight gain, and $w=$ live weight of pig in week $x$.

The trial was terminated when a pig in the study approached the farm's criteria for slaughter, yielding thirteen weeks of data in both the summer and winter trials.

To explore the effect of a forage-based diet on gastric health in pigs, the stomachs of two pigs from each pen in the winter trial $(n=12)$ were assessed at the abattoir for gastric ulceration, rating them on the 0-3 scale described by Mackin et al. [25]. For comparison, six organic pigs reared on a different farm and fed an organic pelleted ration were also assessed for gastric ulceration, using the same scale.

Table 4. Nutritional value of foraged-based total mixed rations for pigs, with different protein sources.

\begin{tabular}{|c|c|c|c|}
\hline \multirow[t]{2}{*}{ Feed value (on fresh weight basis) } & \multicolumn{3}{|c|}{ Composition of forage-based rations, per kilogram of feed (fresh weight) } \\
\hline & Control group ration with soya & Group 1: ration with beans & Group 2: ration with peas \\
\hline Metabolisable energy (ME; $\mathrm{MJ} \mathrm{kg}^{-1}$ ) & 7.30 & 7.11 & 7.12 \\
\hline Crude protein $\left(\mathrm{CP} ; \mathrm{g} \mathrm{kg}^{-1}\right)$ & 116.23 & 93.35 & 89.74 \\
\hline Lysine $\left(\mathrm{g} \mathrm{kg}^{-1}\right)$ & 4.15 & 3.76 & 3.74 \\
\hline Dry matter $\left(\mathrm{g} \mathrm{kg}^{-1}\right)$ & 580.00 & 580.00 & 580.00 \\
\hline
\end{tabular}

\subsection{Statistical Analysis}

Pen was considered the experimental unit. The trial was conducted over two thirteen week periods, from recruitment into the trial at a pen mean of eight to ten weeks of age. Using the mean age of the pigs in each pen rounded to the nearest week, mean daily gain for 'growers' was calculated between 11 and 14 weeks of age, and mean daily gain for 'finishers' was calculated from 15 weeks of age to the end of the experimental periods (day 91, 22 weeks of age).

Pen mean daily live weight gains for each growth phase, grower and finisher, for each diet were compared by use of General Linear Modelling, assessing trial and sex as factors, and pen mean starting weight, number of piglets per pen and pen mean age as covariates. Planned contrasts were performed to compare differences between diets. All data analyses were performed using the statistical package SPSS version 19 (SPSS, Chicago).

\section{Results}

For the grower period (between 11 and 14 weeks of age): sex, number of piglets in the pen, pen mean starting weight and pen mean age of the piglets did not explain a significant proportion of the variation within mean daily live weight gain and thus were not included in the model. An insignificant effect of diet on mean daily gain was observed (ANOVA: $F(2,8)=2.377$, MSE $=0.004, p=0.155$; Figure 1, Table 5), however there was a significant effect of trial (ANOVA: $F(1,8)=9.704$, MSE $=0.004, p=0.014$ ).

For the finisher period (15 weeks of age to the end of the experimental periods (day 91)): trial, sex, pen mean starting weight and number of piglets in the pen explained an insignificant proportion of the variation within mean daily live weight gain. The pen mean age of the piglets, when included as a covariate, was significantly related to mean daily live weight gain (ANCOVA: $F(1,8)=23.52, p=0.001$, partial $\left.\eta^{2}=0.31\right)$. There was a significant effect of diet, after controlling for the effect mean age of piglets (ANCOVA: $F(2,8)=18.943, p=0.001$, partial $\left.\eta^{2}=0.73\right)$. Planned contrasts revealed that there was a significant reduction in mean daily gain for the beans diet compared to the soya diet $(\mathrm{t}(8)=-5.67, \mathrm{p}<0.001)$, but there was no significant difference in mean daily live weight gain between the peas and soya diets $(\mathrm{t}(8)=-1.229, \mathrm{p}=0.254$; Refer to Figure 1 and Table 5). 
Table 5. Pen mean ( \pm standard error) daily live weight gains (DLWGs) of pigs during grower and finisher phases when fed silage-based diets supplemented with either soya (control), beans or peas.

\begin{tabular}{lllll}
\hline Diet & Trial & $\begin{array}{l}\text { Average age at } \\
\text { start of trial (days) }\end{array}$ & $\begin{array}{l}\text { Grower phase } \\
\text { Average daily gain (kg) }\end{array}$ & $\begin{array}{l}\text { Finisher phase } \\
\text { Average daily gain (kg) }\end{array}$ \\
\hline \multirow{2}{*}{ Beans (Group 1) } & Summer (1) & 66.38 & $0.30 \pm 0.02$ & $0.59 \pm 0.02$ \\
& Winter (2) & 65.41 & $0.34 \pm 0.03$ & $0.58 \pm 0.01$ \\
& Combined trials 1\&2 & 65.89 & $0.32 \pm 0.02$ & $0.59 \pm 0.01$ \\
Peas (Group 2) & Summer (1) & 65.37 & $0.28 \pm 0.01$ & $0.66 \pm 0.00$ \\
& Winter (2) & 70.22 & $0.41 \pm 0.03$ & $0.60 \pm 0.02$ \\
& Combined trials 1\&2 & 67.80 & $0.35 \pm 0.04$ & $0.63 \pm 0.02$ \\
Soya (Group 3) & Summer (1) & 63.07 & $0.33 \pm 0.08$ & $0.69 \pm 0.05$ \\
& Winter (2) & 64.65 & $0.50 \pm 0.05$ & $0.69 \pm 0.02$ \\
& Combined trials 1\&2 & 63.86 & $0.42 \pm 0.06$ & $0.69 \pm 0.02$ \\
\hline
\end{tabular}

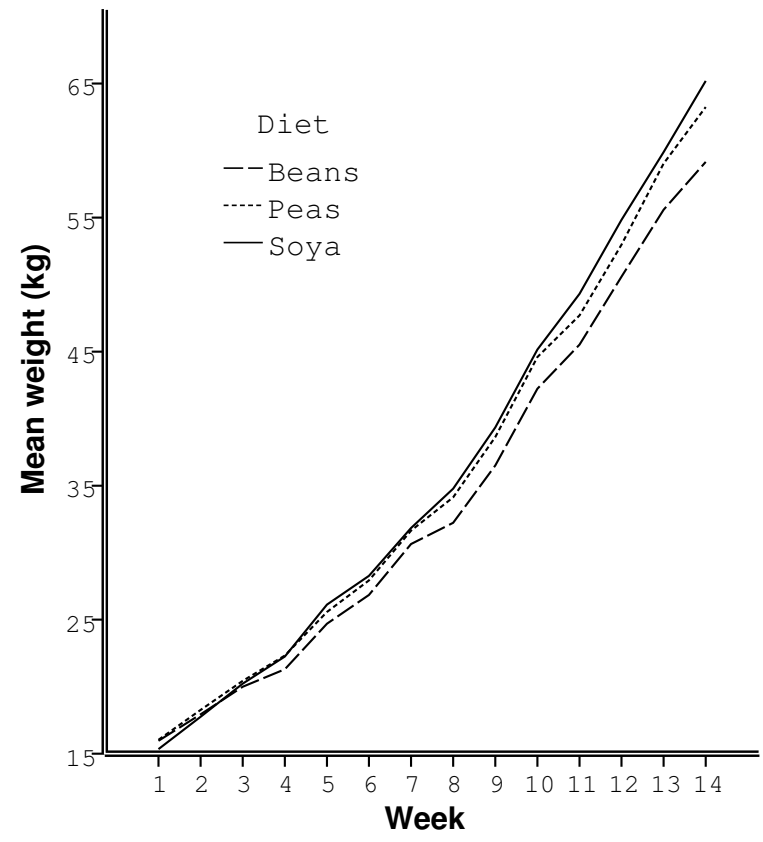

Figure 1. Growth curves depicting the mean pen weights of pigs, consisting of the pen means of both the summer and winter trials, on the control and treatment diets during the 13 week trial periods.

The results of the gastric health assessment in the abattoir showed that seven of the twelve pigs from the current study had no visible lesions, two pigs had evidence of parakeratosis indicative of early inflammation and three pigs had focal, shallow erosions. Six pig carcasses in the abattoir that were not included in the feeding trial and that had received a commercial organic pelleted feed were also examined for gastric lesions. Three of these carcasses had focal shallow erosions and three had diffuse or deep ulcerations. It should be noted that these cannot be treated as a direct control for the trial pigs as they had not been reared under the same management conditions, but they do provide a preliminary comparison for pigs on a commercial diet.

\section{Discussion}

During the pigs' grower phase (11-14 weeks of age), there were no significant differences between the daily live weight gains of pigs on rations containing soya, beans and peas. However, during the finisher phase (15-22 weeks of age), the pen mean daily live weight gain of the pigs on beans was significantly lower than that of the pigs on soya. During the finisher phase, no significant difference was observed between the growth performance of the pigs on the pea ration and those on the soya ration. However, in a practical context it is speculated that the slight shortfall in growth rate observed in the pigs fed the bean ration may be offset by the lower cost of production of beans in the UK. Overall, these results suggest that providing 100 per cent organic feed for pigs combining locally grown protein sources, particularly peas, as part of a lucerne silagebased ration is feasible, although further research to explore the use of these feeds with commercial pig breeds is required. Beans and peas may represent economically viable alternatives to soya, as they can be cheaper to grow than soya is to buy in the UK. However, a comprehensive assessment of the economic implications of replacing soya with peas and beans as part of a forage based ration for pigs is required.

The gastric health assessments in the abattoir suggest that TMR forage-based diets for pigs may be beneficial for gastric health. These preliminary findings are consistent with those of Kortelainen et al. [15] who conducted digestibility trials and suggested that grass silage could provide some available protein and other nutrients for growing pigs, and could prevent the development of gastric ulcerations. A trial is warranted to investigate these effects further by comparing forage-fed pigs to pigs fed a commercial grain-based ration under the same management conditions, in terms of gastric health.

Comparisons between the amounts of energy and nutrients provided by the TMRs per pig each day during this trial, and the daily nutritional requirements of the grower-finisher pigs, revealed a dietary deficiency in lysine 
throughout the trial in all diets. This is one of the main challenges in organic ration formulation, which may restrict the growth rate and feed conversion efficiency of pigs [26]. It is proposed that if this feeding system was utilised for conventional pigs, synthetic amino acids could be added to the TMR formulation to mitigate deficiencies.

During this trial, it was noted that as the pigs were occupied with foraging for the majority of their time, very low levels of aggressive and adverse behaviours were observed (Anna Wharton, University of Oxford, Oxford, UK. Conversation with Laura Higham, 27 January 2015.). These observations were made for the purposes of a separate study in three ten-minute blocks weekly, for the duration of the trial, using behavioural indices adapted from Andersen et al. [27] (Anna Wharton, University of Oxford, Oxford, UK. Conversation with Laura Higham, 27 January 2015.). Aggression in established groups can be caused by competition for food [28] and misdirected foraging behaviour towards pen mates [19]. These aggressive motives may be abated in this system by providing forage-based feed over a large floor area allowing synchronous feeding behaviour for most of the day, as well as manipulable bedding materials. In conjunction with the outcomes of the gastric health assessments, the behaviours observed in this study suggest that there may be positive welfare effects of providing forage-based rations for pigs.

The use of home- grown silage-based rations incorporating locally grown protein sources may be economically more efficient than purchasing commercial organic feeds for growing and finishing pigs. Work is required to evaluate the total cost of production of pigs on forage-based rations, taking in to account the necessary labour and equipment for preparing the rations. The observations in this study have been made despite differences in the crude protein intakes of pigs in the different groups. Future work including the effects of protein source and intake on carcass grades, back fat measurements and other carcass traits would be valuable.

In this paper, we discuss a number of potential welfare, environmental and economic ('3Es') benefits of a novel forage-based feeding system for organic pigs [9]. The use of Gloucester Old Spot pigs in a straw yard system demonstrates the feasibility of this feeding system for a traditional

\section{References}

[1] Zollitsch W. Challenges in the nutrition of organic pigs. Journal of the Science of Food and Agriculture. 2007;87(15):2747-2750.

[2] Nahashon SN, Kilonzo-Nthenge AK. Advances in Soybean and Soybean by-products in monogastric nutrition and health. In: El-Shemy $\mathrm{H}$, editor. Soybean and Nutrition. INTECH Open Access Publisher; 2011. p. 125-130.

[3] West C, Dawkins E, Croft S, Brugere C, Sheate W, breed, which may be applicable to diversifying mixed or arable farms with a mixer wagon and suitable housing facilities. However, it is acknowledged that further work is required to explore the feasibility of this feeding system in commercial pig production facilities. This study could inform future research in the growth performance of pigs of commercial breeds fed forage-based rations, and to compare '3Es' outcomes of forage-based feeds and commercial, conventional rations. Future research may seek to compare the effect of the protein sources on weight gain by balancing the crude protein intakes, thereby providing isonitrogenous diets to the pigs in each group. In addition, work is required to further investigate the effects of forage-based rations on gastric health in pigs as part of a controlled trial.

\section{Conclusions}

In light of the environmental impacts of soybean production, increasing price and concerns for the future availability of soya, UK-grown grain legumes including peas and beans were hypothesized to offer sustainable alternatives as part of a TMR for pigs. A two-part trial in 2012 and 2014 was implemented in Oxford, UK, to test this hypothesis. Notwithstanding the limitations of the current feasibility study that utilises a traditional pig breed in a straw-based unit, results suggest that the inclusion of locally grown sources of protein, particularly peas, may be used to replace soya as part of a forage-based diet feeding strategy for organic pig production from 1 January 2018. This novel feeding strategy may be particularly of interest to farmers seeking options for diversification within mixed or arable farms with suitable facilities.

\section{Acknowledgements}

This research was conducted as part of the CORE Organic II funded project 'Improved contribution of local feed to support $100 \%$ organic feed supply to pigs and poultry' (ICOPP [21]), led by Aarhus University in Denmark with 15 partners across $10 \mathrm{EU}$ countries. The authors are grateful for the funding provided by Defra as part of the European CORE2 Eranet programme to support organic research.

Raffaelli D. Measuring the impacts on global biodiversity goods and services imported into the UK. York, UK: Stockholm Environment Institute; 2013.

[4] Fearnside PM. Soybean cultivation as a threat to the environment in Brazil. Environmental Conservation. $2001 ; 28(1): 23-38$.

[5] Steward C. From colonization to "environmental soy": a case study of environmental and socio-economic valuation in the Amazon soy frontier. Agriculture and Human Values. 2007;24(1):107-122.

[6] Nørgaard JV, Fernández JA. The effect of reduced 
amino acid level and increasing levels of lupin on growth performance and meat content in organic reared pigs. Journal of the Science of Food and Agriculture. 2009;89(3):449-454.

[7] Salgado P, Freire J, Mourato M, Cabral F, Toullec R, Lallès J. Comparative effects of different legume protein sources in weaned piglets: nutrient digestibility, intestinal morphology and digestive enzymes. Livestock Production Science. 2002;74(2):191-202.

[8] The impact of feed costs on the English pig industry. Kenilworth, UK: British Pig Executives; 2012.

[9] FAI Farms Ltd. http://www.faifarms.com/.

[10] Edwards S. Intake of nutrients from pasture by pigs. Proceedings of the Nutrition Society. 2003;62(2):257265.

[11] Danielsen V, Poulsen HD, Jensen SK, Ohlsson C. Økologisk svineproduktion, Udfordringer, muligheder og begrænsninger. In: Hermansen E, editor. Svinenes forsyning med essentielle næringsstoffer og grovfoder; 2000. p. 95-119.

[12] Van Soest PJ. Nutritional ecology of the ruminant. Cornell University Press; 1994.

[13] Jørgensen $H$, Carlson D, Lærke HN. Influence of forage inclusion in the diet on ileal and total tract digestibility. Journal of animal science. 2012;90(4):176178.

[14] Presto MH, Algers B, Persson E, Andersson H. Different roughages to organic growing/finishing pigsInfluence on activity behaviour and social interactions. Livestock Science. 2009;123(1):55-62.

[15] Kortelainen T, Tuori M, Partanen K, Siljander-Rasi H. Digestibility trials of novel feedstuffs. In: Smith J, Gerrard CL, Hermansen JE, editors. Improved Contribution of local feed to support $100 \%$ Organic feed supply to Pigs and Poultry (ICOPP). Elm Farm, UK: The Organic Research Centre; 2014. p. 18.

[16] Rekiel A, Gajewska J, Topol K, Sawosz E. Effect of intensity of feeding on the intestinal microflora of pigs. Polish Journal of Microbiology. 2005;54(4):331-334.

[17] Danielsen V, Hansen LL, Møller F, Bejerholm C, Nielsen S. Production results and sensory meat quality of pigs fed different amounts of concentrate and ad lib clover grass or clover grass silage. In: Proceedings from Ecological Animal Husbandry in the Nordic Countries, NJF-seminar No. 303. Horsens, Denmark; 2000. p. 79-86.
[18] Stolba A, Wood-Gush DGM. The behaviour of pigs in a semi-natural environment. Animal Production. 1989;48(2):419-425.

[19] Studnitz M, Jensen MB, Pedersen LJ. Why do pigs root and in what will they root?: A review on the exploratory behaviour of pigs in relation to environmental enrichment. Applied Animal Behaviour Science. 2007;107(3):183-197.

[20] In: Smith J, Gerrard CL, Hermansen JE, editors. Improved Contribution of local feed to support $100 \%$ Organic feed supply to Pigs and Poultry (ICOPP). EIm Farm, UK: The Organic Research Centre; 2014. Available from: http://orgprints.org/28078/7/28078. pdf.

[21] Improved Contribution of Local Feed to Support 100\% Organic Feed Supply to Pigs and Poultry. Available from: http://www.icopp.eu.

[22] Entering a name in the register of traditional specialities guaranteed (Traditionally Farmed Gloucestershire Old Spots Pork (TSG)). European Commission; 2010. Commission Regulation (EU) No. 675/2010. Available from: http://eur-lex.europa.eu/legalcontent/EN/TXT/?uri=CELEX:32010R0675\#ntr2L_2010197EN.01000101-E0002.

[23] Sealed Envelope Ltd. 2015. Create a blocked randomisation list. Available from: https://www. sealedenvelope.com/simple-randomiser/v1/lists;

[24] Whittemore CT, Hazzledine MJ, Close WH. Nutrient requirement standards for pigs. Penicuik, UK: British Society of Animal Science; 2003.

[25] Mackin AJ, Friendship RM, Wilcock BP, Ball RO, Ayles HL. Development and evaluation of an endoscopic technique permitting rapid visualization of the cardiac region of the porcine stomach. Canadian Journal of Veterinary Research. 1997;61(2):121.

[26] Moore K, Mullan B. Lysine requirements of pigs from 20 to $100 \mathrm{kgs}$ liveweight. Australia: Department of Agriculture and Food; 2010.

[27] Andersen IL, Andenæs H, Bøe KE, Jensen P, Bakken $M$. The effects of weight asymmetry and resource distribution on aggression in groups of unacquainted pigs. Applied Animal Behaviour Science. 2000;68(2):107-120.

[28] Fraser D. The role of behavior in swine production: a review of research. Applied Animal Ethology. 1984;11(4):317-339. 